\title{
ARTIKELEN
}

\section{Antecedenten van een succesvolle organisatieontwikkeling en hun relatie met het leerklimaat van de organisatie: een 'mixed method'-studie}

\author{
Eva Kyndt \& Filip Dochy ${ }^{*}$
}

\begin{abstract}
Deze studie onderzoekt de relatie tussen het leerklimaat van een organisatie en antecedenten van een succesvolle ontwikkeling van organisaties. Om deze algemene onderzoeksvraag te beantwoorden werden twee studies opgezet. In een eerste exploratieve kwalitatieve studie werd nagegaan welke antecedenten organisaties belangrijk achten opdat een succesvolle ontwikkeling van de organisatie mogelijk zou zijn. In totaal werden 55 semi-gestructureerde interviews afgenomen (middenkader en management). Een selectie van de antecedenten die door deze respondenten belangrijk gevonden werden voor de succesvolle ontwikkeling van een organisatie, werd opgenomen in een tweede kwantitatieve survey-studie. De deelnemers in deze studie waren 863 werknemers. De resultaten tonen dat het hebben van beslissingsruimte en initiatief binnen de organisatie - een onderdeel van leerklimaat een positief effect heeft op de organisatiebetrokkenheid, job tevredenheid, motivatie en inzet van werknemers. De steun van collega's en leidinggevenden hangt eveneens positief samen met deze antecedenten.
\end{abstract}

\section{Inleiding}

Onze moderne, westerse samenleving is geëvolueerd naar een kennissamenleving (Hargreaves, 2003). Deze veranderingen, waaronder bijvoorbeeld de innovaties ten gevolge van de huidige technologisering, brengen naast potentiële voordelen ook tal van uitdagingen met zich mee (Vandecasteele \& Bonte, 2005). Ze hebben niet alleen een invloed op de samenleving als geheel, maar eveneens op allerlei maatschappelijke deeldomeinen. Zo is ook de arbeidsmarkt aan verandering onderhevig. De kennisintensiteit van onze arbeidsmarkt neemt toe en kennis veroudert snel. Werknemers moeten zich permanent ontwikkelen. Het verwerven van competenties, levenslang leren en inzetbaarheid van medewerkers staan daarbij centraal (De Rick, Van Valckenborgh \& Baert, 2004). Bovendien wordt de

* Eva Kyndt is verbonden aan de onderzoekseenheid Arbeids- en Organisatiepsychologie en opleidingskunde (O2L) van de KU Leuven. Correspondentieadres: Dekenstraat 2 - PB 3772, B-3000 Leuven, tel. 0032-16-325759, e-mail Eva.Kyndt@ppw.kuleuven.be. Filip Dochy is verbonden aan het centrum voor professionele opleiding \& ontwikkeling en levenslang leren (POOLL) van de KU Leuven. 
competitiviteit van organisaties steeds meer bepaald door investeringen in het menselijk kapitaal. Kennis en competenties zijn immers een krachtige motor voor economische groei (Vandecasteele \& Bonte, 2005). Het vormen, trainen en opleiden van werknemers kan niet langer beperkt blijven tot enkele vrijblijvende bijscholingen (Bergenhenegouwen, Mooijman \& Tillema, 2002). Organisaties moeten in staat zijn een directe verbinding te leggen tussen leren en werken. Ze moeten lerende organisaties zijn waar het besef heerst dat de organisatie in een sterk veranderende omgeving opereert, en die om die reden een bewust beleid voeren om het leren van alle werknemers continu te bevorderen (Pedler, Burgoyne \& Boydell, 1997; Swart, Mann, Brown \& Price, 2005).

Örtenblad (2002) onderscheidt vier aspecten van de lerende organisatie: organisatieleren, werkplekleren, leerklimaat en leerstructuur. Het stimuleren van een positief leerklimaat kan dan ook als een maatregel worden beschouwd om het leren van werknemers te bevorderen. Altink, Schoonman en Seegers (2004) en Van Dongen (2003) beschouwen het leren van werknemers als cruciaal voor het succesvol ontwikkelen van medewerkers. Succesvolle medewerkers dragen op hun beurt bij tot een succesvolle organisatieontwikkeling.

Dit onderzoek is exploratief van aard en bestudeert of het leerklimaat binnen de organisatie samenhangt met de antecedenten ${ }^{1}$ die belangrijk geacht worden voor een succesvolle organisatieontwikkeling. In de kwalitatieve studie wordt nagegaan welke antecedenten binnen organisaties belangrijk geacht worden voor een succesvolle ontwikkeling. Vervolgens wordt in een kwantitatieve studie gekeken naar de relatie tussen het gepercipieerde leerklimaat en de antecedenten die naar voren kwamen in de kwalitatieve studie. Deze 'mixed method'-aanpak laat ons toe om breder en meer in de diepte te kijken naar de antecedenten die een potentiële rol spelen voor een succesvolle organisatieontwikkeling door de actoren uit de praktijk niet enkel te bevragen over specifieke aspecten die voorafgaand geselecteerd werden uit de literatuur. Door deze aanpak te combineren met een kwantitatieve studie kunnen de hypotheses met betrekking tot de relatie tussen een leerklimaat en deze antecedenten worden getoetst bij een grotere steekproef. Binnen dit onderzoek diende de kwalitatieve studie als een grondige voorstudie om te bepalen voor welke concrete antecedenten het belangrijk was om na te gaan of ze gerelateerd kunnen worden aan het leerklimaat van de organisatie.

\section{Theoretische achtergrond}

\subsection{Leerklimaat}

Het concept leerklimaat ontstond in de onderwijskundige literatuur en verwijst naar het geheel van omgevingskenmerken die de leerprestaties van leerlingen bevorderen en belemmeren (Michaud, Forgette-Giroux \& Richard 1989, in Klarenberg, Van Moorsel \& Poell, 1996). Sinds enige tijd wordt het concept ook toegepast op arbeidsorganisaties.

Aan de ene kant zijn er auteurs die leerklimaat relatief algemeen en vaag omschrijven. Zo omschrijft Örtenblad (2002) een gunstig leerklimaat als 'een atmosfeer die leren gemakkelijk en natuurlijk maakt'. Andere auteurs kiezen voor 
een neutralere definitie waarbij de focus niet enkel ligt op het feit dat een leerklimaat uitsluitend gericht zou zijn op het verbeteren van leren. Rothwell (2008) bijvoorbeeld omschrijft het leerklimaat als 'een psychologische gevoel over leren in de organisatie'. Aan de andere kant zijn er ook auteurs die het concreter aanpakken (bijv. Pedler et al., 1997; Van Biesen, 1989). Zij beschrijven het leerklimaat als de omstandigheden in een organisatie die het leren van de leden van de organisatie stimuleren, waardoor de organisatie zichzelf continu kan transformeren (Pedler et al., 1997). Van Biesen (1989) daarentegen omschrijft het leerklimaat als 'de ruimte en stimulans die medewerkers krijgen om zich lerend te gedragen' (p. 9). Een leerklimaat wordt omschreven als de ruimte voor leren die wordt bevorderd, maar niet gecontroleerd (Örtenblad, 2002). Door leerklimaat op een zeer algemene wijze te omschrijven is het echter een weinig daadkrachtig concept dat tevens moeilijk te bevragen is.

Wanneer men leerklimaat concreter wil omschrijven, dan gebeurt dit door het benoemen van de verschillende facetten die een onderdeel uitmaken van het leerklimaat. De meeste auteurs die het begrip leerklimaat trachten te conceptualiseren, doen dit echter niet op bovenstaande algemene wijze, maar omschrijven leerklimaat als het al dan niet aanwezig zijn van bepaalde voorwaarden of aspecten die leren bevorderen en de afwezigheid van drempels en barrières (De Rick et al., 2004). Binnen deze studie is de doelstelling niet om een exhaustief overzicht te geven van alle aspecten die in de literatuur vermeld worden op te nemen. Daarom werd gekozen voor zes facetten die binnen de literatuur het vaakst en meest consistent als onderdeel van het leerklimaat van de organisatie worden beschouwd. Tabel 1 biedt een overzicht van deze zes aspecten (bijv. Pearn, Roderick \& Mulrooney, 1995; Watkins \& Marsick, 1993; Westerberg \& Hauer, 2009).

\subsection{Antecedenten voor een succesvolle organisatieontwikkeling}

In dit onderzoek staat niet het product van de succesvolle organisatie, maar het proces van het succesvol ontwikkelen van organisaties centraal. De focus ligt dus op organisatieontwikkeling. Het succesvol ontwikkelen van organisaties is het succesvol ontwerpen, invoeren en ontwikkelen van faciliterende structuren waardoor medewerkers zich kunnen ontwikkelen om zo tot betere resultaten te komen (Vanderstraeten, 2001). Het uitgangspunt is echter dat een organisatie zich slechts succesvol kan ontwikkelen wanneer de medewerkers zich succesvol ontwikkelen (Van Dongen, 2003). De essentie van een succesvolle organisatie wordt gevormd door mensen die het verschil maken (Altink et al., 2004; Den Breejen, 2009; Pol, 2008). Binnen dit onderzoek werd dus zowel gekeken naar de literatuur over het ontwikkelen van organisaties als de literatuur over het ontwikkelen van individuele medewerkers.

Op basis van de literatuur werden verschillende antecedenten geïdentificeerd die belangrijk geacht worden voor het succesvol ontwikkelen van een organisatie. De definities van de verschillende antecedenten zijn opgenomen in tabel 2. Een eerste antecedent is de job tevredenheid van de werknemers. Taris en Schreurs (2009) concluderen uit hun onderzoek dat job tevredenheid een positieve invloed heeft op de productiviteit van individuele werknemers. Op deze manier draagt job tevredenheid dus bij tot het succesvol functioneren van medewerkers, dat als ver- 


\section{Tabel 1 Facetten van een positief leerklimaat}

\begin{tabular}{|c|c|c|}
\hline Facetten & Definitie & Bronnen \\
\hline $\begin{array}{l}\text { Steun en hulp } \\
\text { van leiding- } \\
\text { gevende }\end{array}$ & $\begin{array}{l}\text { De mate waarin leidinggevenden ondersteunend } \\
\text { en zorgzaam zijn voor hun teamleden. }\end{array}$ & $\begin{array}{l}\text { Pearn et al., 1995; Wes- } \\
\text { terberg \& Hauer, } 2009\end{array}$ \\
\hline $\begin{array}{l}\text { Ontwikkelings- } \\
\text { potentieel }\end{array}$ & $\begin{array}{l}\text { Het continu creëren van leermogelijkheden en } \\
\text { het leerpotentieel en de variatie van taken dra- } \\
\text { gen bij tot leren op het werk. }\end{array}$ & $\begin{array}{l}\text { Ellström, 200I; Mikkelsen, } \\
\text { Saksvik \& Ursin, I998; } \\
\text { Watkins \& Marsick, I993 }\end{array}$ \\
\hline $\begin{array}{l}\text { Collaboratief } \\
\text { potentieel }\end{array}$ & $\begin{array}{l}\text { Het is de mate waarin collega's bereid zijn tot } \\
\text { helpen en tot het delen van informatie. }\end{array}$ & $\begin{array}{l}\text { Pearn et al., 1995; Wat- } \\
\text { kins \& Marsick, 1993; } \\
\text { Westerberg \& Hauer, } \\
2009\end{array}$ \\
\hline $\begin{array}{l}\text { Beslissings- } \\
\text { autonomie }\end{array}$ & $\begin{array}{l}\text { De mate waarin werknemers hun eigen werk } \\
\text { mogen organiseren en ruimte krijgen voor indivi- } \\
\text { duele initiatieven. Een hoge mate van autonomie } \\
\text { bij werknemers over de kenmerken, doelen en } \\
\text { manier van uitvoeren van hun taken is bevorder- } \\
\text { lijk voor de integratie van leren en werken. }\end{array}$ & $\begin{array}{l}\text { Ellström, 200I; Mikkelsen } \\
\text { et al., I998; Pearn et al., } \\
\text { I995; Westerberg \& } \\
\text { Hauer, } 2009\end{array}$ \\
\hline $\begin{array}{l}\text { Innovatief } \\
\text { klimaat }\end{array}$ & $\begin{array}{l}\text { De mate waarin werknemers dingen kunnen } \\
\text { ondernemen en verbeteren en daartoe aange- } \\
\text { moedigd worden. }\end{array}$ & $\begin{array}{l}\text { Sprenger \& Van Oort, } \\
\text { 1998; Watkins \& Marsick, } \\
\text { 1993; Westerberg \& } \\
\text { Hauer, } 2009\end{array}$ \\
\hline Sociale steun & $\begin{array}{l}\text { De mate waarin collega's ondersteunend en } \\
\text { zorgzaam zijn voor elkaar, bijvoorbeeld bij het } \\
\text { oplossen van problemen en het leren van fouten. }\end{array}$ & $\begin{array}{l}\text { Westerberg \& Hauer, } \\
2009\end{array}$ \\
\hline
\end{tabular}

trekpunt van het succesvol ontwikkelen van organisaties wordt gezien (Van Dongen, 2003).

Stress op het werk is een tweede antecedent die naar voren kwam in de literatuur. Uit het onderzoek van Cooper en Cartwright (1994) blijkt dat stress op het werk directe en indirecte gevolgen heeft voor zowel de menselijke als de financiële toestand van de organisatie. Tevens wordt in het onderzoek van Jamal (1984) aangetoond dat de aanwezigheid van stress op het werk een negatief effect heeft op allerlei variabelen die van belang zijn voor de ontwikkeling van de organisatie. Onder meer prestatie, motivatie, absenteïsme, vermoeidheid en retentie worden negatief beïnvloed. Samengevat kan gesteld worden dat de afwezigheid van stress op het werk een voordeel biedt voor de ontwikkeling van de organisatie (Cooper \& Cartwright, 1994; Jamal, 1984). Voorgaand onderzoek heeft aangetoond dat stress op het werk negatief samenhangt met het welbevinden van werknemers (Cooper \& Cartwright, 1994). Het is belangrijk dat werkgevers oog hebben voor het welbevinden van werknemers, aangezien dit een rechtstreekse invloed kan hebben op de uitkomsten van de organisatie (Cartwright \& Cooper, 2009; Rath \& Harter, 2010).

Organisatiebetrokkenheid heeft een invloed op verschillende antecedenten die mede het succesvol functioneren van de medewerkers bepalen. Uit verschillende onderzoeken blijkt dat organisatiebetrokkenheid een rechtstreekse en positieve invloed heeft op motivatie, productiviteit en job tevredenheid van medewerkers 
Dit artikel van Boom Lemma Tijdschriften is gemaakt voor KU Leuven - Hilde van Kiel

Antecedenten van een succesvolle organisatieontwikkeling en hun relatie met het leerklimaat van de organisatie: een 'mixed method'-studie

Tabel 2 Definities antecedenten literatuur

\begin{tabular}{|c|c|}
\hline Antecedent & Omschrijving \\
\hline Job tevredenheid & $\begin{array}{l}\text { Job tevredenheid verwijst naar een intern gevoel dat zich uit als een posi- } \\
\text { tieve affectie ten aanzien van de job of eerder als een cognitieve evaluatie } \\
\text { van de job (Brief, 1998; Sempane, Rieger \& Roodt, 2002). }\end{array}$ \\
\hline Job stress & $\begin{array}{l}\text { Job stress is een reactie die afhankelijk is van hoe omgeving en persoon op } \\
\text { elkaar afgestemd zijn. Het kan worden veroorzaakt op vier verschillende } \\
\text { niveaus: het sociaal-politieke niveau, het organisatorische niveau, het } \\
\text { groepsniveau en het individuele niveau (Dalgran \& Gard, 2009). }\end{array}$ \\
\hline Welbevinden & $\begin{array}{l}\text { Het welbevinden van werknemers omvat hun fysische evenals psychische } \\
\text { welbevinden. Bij het fysische welbevinden van werknemers, spreken Rath } \\
\text { en Harter (2010) over de gezondheid van werknemers en de energie die ze } \\
\text { hebben om hun dagelijkse taken te vervullen. Het psychische welbevinden } \\
\text { beschrijven ze als hoe goed werknemers zich in hun vel voelen. }\end{array}$ \\
\hline $\begin{array}{l}\text { Organisatie- } \\
\text { betrokkenheid }\end{array}$ & $\begin{array}{l}\text { Organisatiebetrokkenheid refereert naar het engagement van werknemers } \\
\text { ten aanzien van de gehele organisatie (Blau et al., 2008). }\end{array}$ \\
\hline $\begin{array}{l}\text { Carrièrebewust- } \\
\text { heid }\end{array}$ & $\begin{array}{l}\text { Carrièrebewustheid is de mate waarin een werknemer bewust is van de } \\
\text { eigen sturingsmogelijkheden betreffende zijn carrière en de kansen die de } \\
\text { werknemer heeft om deze sturingsmogelijkheden tot uiting te brengen } \\
\text { (Raggl \& Troman, 2007). }\end{array}$ \\
\hline $\begin{array}{l}\text { Participatie aan } \\
\text { leren }\end{array}$ & $\begin{array}{l}\text { Participatie aan leren omvat deelname aan alle vormen van leren die ver- } \\
\text { band houden met de werksfeer. Hieronder wordt zowel het leren on-the- } \\
\text { job als het leren off-the-job verstaan. }\end{array}$ \\
\hline Transfer & $\begin{array}{l}\text { Transfer wordt omschreven als de generalisatie van nieuwe kennis en vaar- } \\
\text { digheden die geleerd zijn tijdens trainingen naar de werkvloer toe (Hyun, } \\
\text { 2007). }\end{array}$ \\
\hline Retentiebeleid & $\begin{array}{l}\text { Retentiebeleid kan worden verstaan als de inspanningen die een werkgever } \\
\text { doet om werknemers te behouden (Connell \& Phillips, 2003). }\end{array}$ \\
\hline Innovatiebeleid & $\begin{array}{l}\text { De inspanning die een werkgever doet om nieuwe ideeën, producten of } \\
\text { procedures binnen de organisatie te introduceren en toe te passen. Hierbij } \\
\text { ligt de nadruk vooral op significante verbeteringen (Martins \& Terblanche, } \\
\text { 2003). }\end{array}$ \\
\hline
\end{tabular}

(DeCotiis \& Summers, 1987; Sree Rekha \& Kamalanabhan, 2010). Voorts blijkt dat ook de objectieve prestaties van de medewerkers, zoals arbeidskosten en productiekosten, door organisatiebetrokkenheid voorspeld worden (DeCotiis \& Summers, 1987).

Een volgende antecedent van een succesvolle ontwikkeling van de organisatie die naar voren komt in de literatuur, is de carrièrebewustheid van werknemers. Jackson, Knight, Lindholm en Rothwell (2005) geven aan dat wanneer werknemers hun carrière kunnen plannen, dat ook verschillende voordelen heeft voor de organisatie. Zo zal de retentie binnen de organisatie hierdoor worden verhoogd. Werkgevers die niet wensen te investeren in carrièreplanning, lijken een hoger personeelsverloop te kennen.

Organisaties zijn meer en meer onderhevig aan constante uitdagende, ingrijpende en snel opeenvolgende veranderingen. Deze veranderingen vereisen dat medewerkers constant deelnemen aan zowel on-the-job als off-the-job leeractiviteiten. Dit leren draagt ertoe bij dat men zijn competenties verder kan ontwikkelen 
Eva Kyndt \& Filip Dochy

(Coetzer, 2007; Mayer \& Solga, 2008). Aangezien competente medewerkers de basis vormen voor succesvolle organisatieontwikkeling, is participatie aan leren een belangrijke antecedent voor deze ontwikkeling. De meta-analyse van Alliger, Tannenbaum, Bennett, Traver en Shortland (1997) toont echter dat de correlatie tussen formeel georganiseerd leren en de transfer naar de werkplek gering is. Hieruit blijkt dat de positieve gevolgen van leren voor de organisatie verloren gaan wanneer er geen transfer is. Transfer is dus een extra voorwaarde opdat leeractiviteiten zouden bijdragen aan het verder ontwikkelen van de organisatie (Konings, Sels \& Vanormelingen, 2008).

Tot slot wordt ook het beleid van een organisatie ten aanzien van de retentie van werknemers en innovatieprocessen als een antecedent beschouwd in de literatuur. Rammant en Pepermans (2003) wijzen erop dat het belangrijk is dat een werkgever zich bewust is van de strategieën die het mogelijk maken om werknemers te behouden. Zij vermelden dan ook dat organisaties met een retentiebeleid uiteindelijk het meest succesvol zullen zijn (Rammant \& Pepermans, 2003). Een innovatiebeleid kan op zijn beurt weer bijdragen tot een succesvolle organisatieontwikkeling. Het Jaarboek Personeelsmanagement 2010 (Biemans, 2010) geeft aan dat bedrijven die succesvol uit de vorige recessie kwamen, flink hadden geïnvesteerd in innovatie en ontwikkeling. Ook Robbins (2005) meent dat moderne succesvolle organisaties innovatie moeten stimuleren en veranderingen leren doorvoeren.

\section{Studie 1: kwalitatieve studie}

In het eerste exploratieve luik van dit onderzoek willen we nagaan welke antecedenten voor een succesvolle ontwikkeling belangrijk geacht worden door de organisaties. Hierbij wordt op een deductieve en inductieve wijze te werk gegaan (zie hierna).

\subsection{Methode}

\section{- Deelnemers}

Voor dit onderzoek zijn 55 deelnemers gerekruteerd uit twintig verschillende organisaties (> 10 werknemers), verspreid over Vlaanderen. Er werden uitsluitend medewerkers vanuit het middenkader of leidinggevenden geïnterviewd, omdat zij meer weten van de organisatorische kant van het bedrijf, en een beter zicht hebben op acties en maatregelen die ondernomen worden om het succes van de organisatie te stimuleren. Daarbij werd gestreefd naar een evenwicht tussen de profiten non-profitsector. Profitorganisaties $(n=12)$ zijn organisaties die diensten of goederen verkopen aan klanten met het doel om winst te maken. Bij non-profitorganisaties $(n=8)$ is het aanvangspunt een maatschappelijk probleem, zoals de nood aan ziekenzorg, en betaalt de klant niet of slechts gedeeltelijk de kosten van de gekochte goederen en gebruikte diensten (Schermer \& Quint, 2008). Gezien de inherente verschillende doelstellingen van beide sectoren die mede vorm geven aan wat 'succesvol zijn' betekent voor een organisatie, werd er in dit deel van het 
Dit artikel van Boom Lemma Tijdschriften is gemaakt voor KU Leuven - Hilde van Kiel

Antecedenten van een succesvolle organisatieontwikkeling en hun relatie met het leerklimaat van de organisatie: een 'mixed method'-studie

Tabel $3 \quad$ Kenmerken deelnemers kwalitatieve studie

\begin{tabular}{lcc}
\hline Kenmerk & Aantal deelnemers & Percentage \\
\hline Geslacht & 39 & 71 \\
Man & 16 & 29 \\
Vrouw & & \\
Werkervaring & 3 & 6 \\
$0-5$ jaar & 8 & 16 \\
5 tot 10 jaar & 8 & 16 \\
10 tot 20 jaar & 31 & 62 \\
20 jaar of meer & &
\end{tabular}

onderzoek voor gekozen om voor elke sector een aparte analyse uit te voeren. Zie tabel 3 voor meer deelnemerskenmerken.

- Interview

De kwalitatieve data werden verzameld door middel van semi-gestructureerde interviews. Deze aanpak maakte het mogelijk de antecedenten die worden beschreven in de literatuur te bespreken en tegelijkertijd de flexibiliteit te bewaren om nieuwe antecedenten verder te exploreren (Cohen, Manion \& Morrison, 2007). Tijdens de interviews werd aan de deelnemers gevraagd welke antecedenten zij belangrijk achtten voor het succesvol ontwikkelen van de organisatie en waarom ze dit vonden (inductieve werkwijze). In het eerste deel van het interview werden open vragen gesteld om de deelnemers niet te sturen in hun antwoord. De hoofdvraag was: 'Welke factoren dragen bij tot het succesvol ontwikkelen van uw bedrijf?' Mogelijke bijvragen waren: 'Wat begrijpt u onder (vernoemd antecedent)? Wat bedoelt u daar precies mee? Kunt u een voorbeeld geven?' Daarnaast werd ook steeds gevraagd aan deelnemers of ze het een belangrijk antecedent vonden en waarom dit was (deductieve werkwijze). In het tweede deel van het interview werden de variabelen uit de literatuur die nog niet waren genoemd, voorgelegd met de vraag of dit in hun ogen een antecedent was van een succesvolle ontwikkeling. De interviews duurden gemiddeld 45 minuten. Drie pilotinterviews werden gedaan om de begrijpbaarheid van de vragen na te gaan. Op basis van deze interviews werden enkele wijzigingen in de interviewleidraad gemaakt.

\section{- Analyse}

De analyse van het kwalitatieve onderzoek bestond uit vier fases: transcriberen, een verticale analyse, een horizontale analyse en een selectie van de belangrijkste antecedenten per sector (Decorte \& Zaitch, 2009). De analyse van de transcripties gebeurde met behulp van het dataverwerkingsprogramma Nvivo. Tijdens de verticale analyse werd elk interview afzonderlijk doorgenomen. Hierbij werden codes toegekend aan betekenisvolle citaten. Er werd gestart met open coderen vanuit een a-priori-benadering (Mortelmans, 2009). Hiervoor werd vertrokken van een 
Eva Kyndt \& Filip Dochy

basisstamboom van codes. Deze stamboom bevatte alle antecedenten die een invloed konden hebben op het succesvol ontwikkelen van de organisatie die in de interviewleidraad waren opgenomen op basis van de literatuur (deductie). Op basis van de interviews werd de basisstamboom aangepast en aangevuld (inductie) tot een definitieve stamboom. De codering van ieder interview gebeurde door twee onderzoekers. Wanneer een discrepantie werd vastgesteld, werd samen besproken of een code al dan niet gewijzigd diende te worden. Naast de verticale analyse werd ook een horizontale analyse uitgevoerd, waarbij dezelfde codes over de verschillende interviews heen met elkaar vergeleken worden (Levering \& Smeyers, 2003). De belangrijkheid van een code werd bepaald op basis van inhoud en gewicht. Het gewicht werd bepaald door het aantal citaten in alle interviews en het aantal interviews waarin de code voorkwam.

\subsection{Resultaten}

Voor de profitsector was het eerste belangrijke antecedent job tevredenheid van de werknemers (24 deelnemers (d); 72 citaten (c)). In de kwantificering staat 24 voor het aantal personen dat deze antecedent aanhaalde als belangrijk, terwijl 72 staat voor het aantal gecodeerde citaten. Dit getal geeft een indicatie of er veel of weinig over deze antecedent gesproken werd. Job tevredenheid wordt dus beschouwd als een belangrijk antecedent omdat deze door veel personen aangehaald werd en dit ook vaak werd aangehaald door de respondenten. Er werd eveneens rekening gehouden met de inhoud van de gecodeerde citaten. Hierdoor werd bijvoorbeeld participatie aan leren (25d; 134c) - hoewel dit initieel wel een belangrijk antecedent leek te zijn - niet opgenomen. Deze antecedent werd genoemd door 25 personen. $\mathrm{Na}$ analyse bleek dat participatie aan leren meestal werd aangehaald omdat dit een voor de hand liggend element bleek en de respondenten eerder het hele opleidingsaanbod meedeelden dan de link te leggen met het succesvol ontwikkelen van hun organisatie.

Als tweede antecedent kwam motivatie en inzet (20d; 50c) naar voren. De respondenten gaven aan dat het belangrijk is voor het succesvol ontwikkelen van de organisatie dat een medewerker gemotiveerd is en tevreden blijft om goed werk te leveren.

'Mensen die graag ergens zijn, die presteren ook beter. Tegenover iemand die naar hier komt en die eigenlijk zijn uurtjes klopt.'

Motivatie kan de vorm, intensiteit en duur van het werkgedrag bepalen (Pinder, 1998; Tziner, Fisher, Senior \& Weisberg, 2007). Inzet werd verbonden aan motivatie omdat beide vaak samen voorkwamen in de antwoorden van de respondenten.

Als derde en vierde antecedent werden organisatiebetrokkenheid (23d; 45c) en welbevinden (23d; 70c) geselecteerd. De antecedenten bedrijfsimago en goede samenwerking werden ook als belangrijk bestempeld. Deze antecedenten werden echter maar in enkele interviews aangehaald. 
Voor de non-profitsector werden vele antecedenten belangrijk bevonden voor het succesvol ontwikkelen van organisaties. Een groot aantal van deze antecedenten werd echter maar in enkele interviews aangehaald en deze werden dus niet algemeen belangrijk geacht. Deze antecedenten waren: algemeen management (3d; $3 c)$, bedrijfsimago (14d; 24c), het verleggen van grenzen (9d; 13c), communicatie (11d; 23c), concurrentie (6d; 6c), correcte attitude (5d; 10c), ervaringen uitwisselen (4d; 7c), goede werksfeer (3d; 4c), kwaliteitsmanagement (7d; 11c), missie en visie (15d; 19c), psychologische veiligheid (8d; 10c), op de hoogte van het aanbod $(4 \mathrm{~d} ; 6 \mathrm{c})$, en voeling met het personeel (3d; 4c). De antecedent transfer van geleerde kennis of vaardigheden werd eveneens niet opgenomen omdat de respondenten wel zeiden dat het belangrijk was, maar tegelijkertijd bestonden er niet veel maatregelen binnen de organisatie die aantoonden dat het echt belangrijk was. Transfer werd vaak als een automatisme beschouwd.

'Ja, maar hier worden opleidingen gegeven in functie van uw werk. (...) Dus elke opleiding die we volgen, gebruiken we. Anders volgen we ze gewoon niet.'

Leiderschap kwam naar voren als een van de belangrijkste antecedenten voor de non-profitsector (20d; 51c). Leiderschap werd door de respondenten vooral als waarderend en voorwaardenscheppend leiderschap gezien. Een tweede kenmerk van een goede leider was dat hij ook als een coach moet handelen en de werknemers waar nodig moet kunnen ondersteunen om zo een inspirerend voorbeeld voor anderen te vormen.

'Als er iets is, ben ik daar altijd graag van op de hoogte. (...) We zijn hier enerzijds collega's maar langs de andere kant ook een coach, een beetje mental coach, dat is zeker niet onbelangrijk voor ons succes.'

Een inspirerende leider kan ervoor zorgen dat de activiteiten van de werknemers maximaal bijdragen tot de organisatiedoelstellingen (Eagly, Johannesen-Schmidt \& Van Engen, 2003; Noppe, Lernout, Heye \& Frederix, 2006). Bij dergelijk leiderschap is de leidinggevende vooral een inspirerend voorbeeld voor anderen.

Net zoals bij de profitsector kwam ook in de non-profitsector job tevredenheid (30d; 89c) naar voren als een belangrijke antecedent. Een derde belangrijke antecedent voor de non-profitsector is alignment (15d; 54c). De respondenten verstonden onder deze term dat werknemers optimaal op elkaar afgestemd zijn en allemaal naar dezelfde doelen streven.

'Dat is toch de bedoeling die mensen allemaal in dezelfde richting te laten werken, die te coachen, te sturen. En vooral ook als coördinator van één team het geheel van de sociale dienst te bewaken. Als ik hier mijn belangen ga verdedigen en dat staat haaks tegenover de coördinator van een welzijnsbureau, ja dan hebben wij als sociale dienst wel een probleem.'

Dit komt overeen met de definiëring van alignment die Kouwenhoven, Van Hooft en Hoeksema (2005) geven. Alignment is de optimale afstemming tussen de orga- 
nisatiedoelen en de werknemers. Hiermee wordt bedoeld dat de verschillende delen van de organisatie op eenzelfde lijn worden gebracht (Harrison, 1990). Motivatie en inzet (20d; 65c) en stress op het werk (30d; 65c) vervolledigden de top vijf van de belangrijkste antecedenten voor de non-profitsector. Klanttevredenheid (17d; 31c), middelen (17d; 31c) en werving en selectie (17d; 34c) werden ook als belangrijke antecedenten erkend, maar werden niet opgenomen bij de vijf belangrijkste antecedenten.

In conclusie kunnen we stellen dat de antecedenten job tevredenheid, en motivatie en inzet zowel door respondenten van de profit- als non-profitsector als heel belangrijk worden beschouwd voor het succesvol ontwikkelen van hun organisatie. Er bleken echter ook verschillen te bestaan tussen beide sectoren. Zo waren de antecedenten stress op het werk, alignment en leiderschap vooral van belang voor de non-profitsector en minder voor de profitsector. De antecedenten organisatiebetrokkenheid en welbevinden daarentegen werden in de profitsector als belangrijker beschouwd dan in de non-profitsector.

\section{Studie 2: kwantitatieve studie}

Het kwantitatief onderzoek focust zich op de samenhang tussen leerklimaat - gedefinieerd als het geheel van de zes dimensies die omschreven werden in de theoretische achtergrond - en de antecedenten die in de kwalitatieve studie geïdentificeerd werden als belangrijk voor een succesvolle organisatieontwikkeling. Binnen dit kwantitatief onderzoek was het echter niet mogelijk om alle antecedenten op te nemen. De verwachtingen met betrekking tot de grootte van de steekproef leidden tot de beslissing om geen apart kwantitatief onderzoek op te zetten voor de profit- en non-profitsector. Daarom werd een selectie van antecedenten gemaakt die informatief was voor beide sectoren. Naast de gemeenschappelijk belangrijk geachte antecedenten - motivatie en inzet, en job tevredenheid werd er voor elke sector nog één antecedent mee opgenomen. Voor de begripsvaliditeit van de meting was het belangrijk dat antecedenten gekozen werden die gekend zijn en begrepen worden door alle werknemers binnen een organisatie. Daarom werd ervoor gekozen om voor de profitsector organisatiebetrokkenheid en voor de non-profitsector stress op het werk op te nemen en niet alignment. Leiderschap werd niet als onafhankelijke variabele opgenomen, omdat het nauw verwante 'steun van de leidinggevende' als een onderdeel van het leerklimaat werd beschouwd.

De onderzoeksvragen voor dit kwantitatieve onderzoek waren:

- Wat is de relatie tussen leerklimaat en job tevredenheid?

- Wat is de relatie tussen leerklimaat en organisatiebetrokkenheid?

- Wat is de relatie tussen leerklimaat en stress op het werk?

- Wat is de relatie tussen leerklimaat en motivatie en inzet? 
Dit artikel van Boom Lemma Tijdschriften is gemaakt voor KU Leuven - Hilde van Kiel

Antecedenten van een succesvolle organisatieontwikkeling en hun relatie met het leerklimaat van de organisatie: een 'mixed method'-studie

Tabel $4 \quad$ Kenmerken deelnemers kwantitatieve studie

\begin{tabular}{|c|c|c|}
\hline Kenmerk & Aantal deelnemers & Percentage \\
\hline \multicolumn{3}{|l|}{ Geslacht } \\
\hline Man & 346 & 40.47 \\
\hline Vrouw & 509 & 59.53 \\
\hline \multicolumn{3}{|l|}{ Opleidingsniveau } \\
\hline Geen diploma & 10 & 1.17 \\
\hline Lager onderwijs & 6 & .70 \\
\hline Secundair onderwijs & 198 & 23.24 \\
\hline Professionele bachelor & 356 & 41.78 \\
\hline Academische bachelor & 22 & 2.58 \\
\hline Master & 253 & 29.69 \\
\hline Doctoraat & 5 & .59 \\
\hline Andere & 2 & .23 \\
\hline \multicolumn{3}{|l|}{ Sector } \\
\hline Profit & 337 & 40.08 \\
\hline Non-profit & 526 & 59.92 \\
\hline \multicolumn{3}{|l|}{ Contract } \\
\hline Arbeider & 76 & .09 \\
\hline Bediende & 771 & 89.34 \\
\hline Zelfstandige & 13 & .02 \\
\hline Andere & 3 & .01 \\
\hline \multicolumn{3}{|l|}{ Leidinggevende } \\
\hline Ja & 285 & 33.06 \\
\hline Nee & 577 & 66.94 \\
\hline \multicolumn{3}{|l|}{ Organisatiegrootte } \\
\hline $25-250$ medewerkers & 436 & 50.52 \\
\hline$>250$ medewerkers & 427 & 49.48 \\
\hline
\end{tabular}

\subsection{Methode}

- Deelnemers

Deelnemers aan de kwantitatieve studie waren 863 werknemers uit 292 verschillende organisaties. De gemiddelde deelnemer was 38.25 jaar oud $(S D=10.67)$ en had 9.49 dienstjaren $(S D=8.99)$. Een overzicht van de andere kenmerken van deze deelnemers is terug te vinden in tabel 4. 


\section{- Survey}

De data voor deze tweede studie zijn verzameld door middel van een vragenlijst, samengesteld uit betrouwbare en valide schalen van voorgaand onderzoek. Deze vragenlijst werd op papier verspreid onder potentiële deelnemers via de human resource afdeling van verschillende bedrijven. Om de respons te verhogen werden individuele werknemers ook rechtstreeks gecontacteerd. De variabele leerklimaat is gemeten aan de hand van de Learning Climate Questionnaire van Westerberg en Hauer (2009). Dit instrument bestaat uit 26 items, onderverdeeld in zes subschalen: collaboratief potentieel, beslissingsautonomie, steun van de leidinggevende, ontwikkelingspotentieel, sociale steun en innovatief klimaat.

De afhankelijke variabelen stress op het werk (vijf items) en organisatiebetrokkenheid (vier items) werden gemeten door twee schalen, ontleend aan het onderzoek van Staples, Hulland en Higgins (1998). Aan de schaal stress op het werk werd een extra item toegevoegd zodat het instrument beter tegemoetkwam aan de definitie van stress op het werk die eerder werd vermeld. Het toegevoegde item was: 'Ik heb het gevoel dat ik niet kan voldoen aan de verwachtingen die aan mij worden gesteld.' Motivatie en inzet werden gemeten door zes items uit de vragenlijst van Van den Berg (2009). Job tevredenheid (6 items) werd gemeten met het instrument van Curry, Wakefield, Price en Meuller (1986). Alle schalen - met uitzondering van de schaal voor motivatie en inzet - werden vertaald vanuit het Engels naar het Nederlands, de moedertaal van de participanten. Dit gebeurde in overeenstemming met de richtlijnen van de Internationale Test Commissie (Hambleton, 1994). Bovendien werd de vragenlijst door verschillende werknemers op voorhand nagelezen om de verstaanbaarheid van de vragen te verhogen. De stellingen in de vragenlijst werden beoordeeld op een 5-puntschaal, gaande van ' 1 = helemaal niet akkoord' tot ' $5=$ helemaal akkoord'. ${ }^{2}$

Aangezien de meerderheid van de schalen in deze vragenlijst vertaald werd naar het Nederlands, kan er niet zomaar van worden uitgegaan dat de structuur van de originele schalen geldt voor de vertaalde. Daarom is door middel van twee exploratieve factoranalyses (maximum likelihood - varimax rotatie) - één voor de afhankelijke en één voor de onafhankelijke variabelen - de onderliggende structuur van de vertaalde vragenlijst nagegaan. Daarnaast is de interne consistentie (Cronbach's $\alpha$ ) berekend om de betrouwbaarheid te bepalen. Voor leerklimaat werden drie factoren geselecteerd op basis van het 'screeplot', de 'eigenvalues' en de verklaarde variantie van de factoren: beslissingsruimte en mogelijkheden tot het nemen van initiatief $\left(\alpha=.91, R^{2}=28 \%\right)$, sociale steun van de collega's ( $\alpha=.79, R^{2}=16 \%$ ) en sociale steun van de leidinggevende $\left(\alpha=.74, R^{2}=11 \%\right.$ ). De tweede analyse resulteerde in vier antecedenten voor een succesvolle organisatieontwikkeling: organisatiebetrokkenheid en job tevredenheid ( $\alpha=.88, R^{2}=25 \%$ ), stress op het werk ( $\left.\alpha=.70, R^{2}=12 \%\right)$, motivatie en inzet ( $\left.\alpha=.61, R^{2}=10 \%\right)$, en negatieve emoties bij faalervaringen ( $\alpha=.69, R^{2}=7 \%$ ).

\section{- Analyses}

De analyses zijn gestart met het berekenen van de beschrijvende statistieken van de verschillende schalen en correlaties tussen de schalen. Indien de afhankelijke 
Dit artikel van Boom Lemma Tijdschriften is gemaakt voor KU Leuven - Hilde van Kiel

Antecedenten van een succesvolle organisatieontwikkeling en hun relatie met het leerklimaat van de organisatie: een 'mixed method'-studie

Tabel 5 Beschrijvende statistieken variabelen kwantitatieve studie

\begin{tabular}{llll}
\hline Variabele & $\mathbf{N}$ & $\mathbf{M}$ & $\mathbf{S D}$ \\
\hline Beslissing \& initiatief & 855 & 3.65 & 0.65 \\
Sociale steun collega's & 862 & 3.90 & 0.85 \\
Sociale steun leidinggevende & $86 \mathrm{I}$ & 3.11 & 0.72 \\
Betrokkenheid \& tevredenheid & 862 & 4.49 & 0.43 \\
Job stress & 862 & 3.76 & 0.80 \\
Motivatie \& inzet & 852 & 3.55 & 0.73 \\
Negatieve emoties falen & 861 & 3.80 & 0.65 \\
\hline
\end{tabular}

5-puntsschalen

variabelen onderling gecorreleerd zijn, is een multivariate aanpak nodig. Aangezien de data verzameld werden bij deelnemers uit verschillende organisaties (geneste data), diende eerst te worden nagegaan of een multilevel-aanpak nodig was. Ook wanneer er geen organisatiekenmerken (zogenaamde level-2 voorspellers) opgenomen worden, is het belangrijk om na te gaan of de variantie op het niveau van de organisatie mee gemodelleerd dient te worden (bijv. door middel van een random intercept). Om te bepalen of een multilevel-aanpak nodig was, is de Intra Class Coëfficiënt (ICC) en het design effect berekend op basis van een random intercept model zonder voorspellers (Kyndt \& Onghena, in press). Een ICC gelijk aan .16 en een design effect gelijk aan 1.3 gaven aan dat het niet nodig was om een multilevel-aanpak te hanteren (Peugh, 2010). De onderzoeksvragen zijn bijgevolg beantwoord op basis van een multivariate meervoudige regressieanalyse. Alle analyses werden uitgevoerd met de R software (R Development Core Team, 2012).

\subsection{Resultaten}

De analyses werden gestart met het berekenen van de beschrijvende statistieken van de variabelen die opgenomen werden in deze studie. Tabel 5 geeft een overzicht van deze gegevens. De correlatie-analyse geeft aan dat onze afhankelijke variabelen onderling gecorreleerd zijn en dat een multivariate meervoudige regressie aangewezen is (zie tabel 6).

\section{- Organisatiebetrokkenheid en job tevredenheid}

De eerste twee onderzoeksvragen van dit onderzoek worden samen beantwoord. $\mathrm{Na}$ de factoranalyse werd duidelijk dat de factoren organisatiebetrokkenheid en job tevredenheid groepeerden in één factor. De resultaten van de multivariate regressie (tabel 7) geven aan dat organisatiebetrokkenheid en tevredenheid relatief sterk en positief samenhangen met de verschillende aspecten van een leerklimaat. Deze positieve relaties duiden aan dat naarmate de steun van collega's en leidinggevende en beslissingsruimte en initiatief toeneemt, ook de betrokkenheid en job tevredenheid toenemen en omgekeerd. In totaal wordt $48.96 \%$ van de vari- 


\section{Tabel $6 \quad$ Resultaten correlatie-analyse}

\begin{tabular}{|c|c|c|c|c|c|c|}
\hline & I & 2 & 3 & 4 & 5 & 6 \\
\hline I. Beslissing \& initiatief & I & & & & & \\
\hline 2. Sociale steun collega's & $.43 * * *$ & 1 & & & & \\
\hline 3. Sociale steun leidinggevende & $.48^{* * *}$ & $.54 * * *$ & I & & & \\
\hline 4. Betrokkenheid \& tevredenheid & $.64 * * *$ & $.48 * * *$ & $.53 * * *$ & $\mathrm{I}$ & & \\
\hline 5. Job stress & $.18 * * *$ & $-.14 * * *$ & $-.21 * * *$ & $-.08 *$ & I & \\
\hline 6. Motivatie \& inzet & $.38 * * *$ & $.28 * * *$ & $.28 * * *$ & $.47^{* *}$ & .03 & I \\
\hline 7. Negatieve emoties falen & $.20 * * *$ & $.13^{* *}$ & $.10 * * *$ & $.25 * * *$ & $.32 * * *$ & $.27 * * *$ \\
\hline
\end{tabular}

$* \mathrm{p}<.05 ; * * \mathrm{p}<.01 ; * * * \mathrm{p}<.001$

Coëfficiënt: $>$.10: klein effect, > .30 gemiddeld effect, en $>.50$ groot effect (Cohen, 1988).

Tabel $7 \quad$ Resultaten multivariate regressie

\begin{tabular}{|c|c|c|c|c|c|c|c|c|c|c|c|c|c|c|c|c|}
\hline & \multicolumn{4}{|c|}{$\begin{array}{l}\text { Betrokkenheid \& } \\
\text { tevredenheid }\end{array}$} & \multicolumn{4}{|c|}{ Job stress } & \multicolumn{4}{|c|}{ Motivatie \& inzet } & \multicolumn{4}{|c|}{$\begin{array}{l}\text { Negatieve emoties } \\
\text { falen }\end{array}$} \\
\hline & B & Se & $t$ & $p$ & B & $\mathrm{Se}$ & $t$ & $p$ & B & $\mathrm{Se}$ & $t$ & $p$ & B & $\mathrm{Se}$ & $t$ & $p$ \\
\hline $\begin{array}{l}\text { Inter- } \\
\text { cept }\end{array}$ & 0.91 & 0.10 & 8.69 & $<.001$ & 3.42 & 0.15 & 22.96 & $<.001$ & 3.45 & 0.09 & 39.41 & $<.001$ & 3.00 & 0.19 & 15.83 & $<.001$ \\
\hline $\begin{array}{l}\text { Beslis- } \\
\text { sen }\end{array}$ & 0.41 & 0.03 & 16.38 & $<.001$ & 0.37 & 0.04 & 1.28 & $<.001$ & 0.17 & 0.02 & 8.19 & $<.001$ & 0.19 & 0.05 & 4.18 & $<.001$ \\
\hline $\begin{array}{l}\text { Col- } \\
\text { lega's }\end{array}$ & 0.17 & 0.03 & 5.83 & $<.001$ & -0.15 & 0.04 & -3.59 & $<.001$ & 0.07 & 0.03 & 2.97 & $<.01$ & 0.08 & 0.05 & 1.50 & .12 \\
\hline $\begin{array}{l}\text { Leiding- } \\
\text { gevende }\end{array}$ & 0.16 & 0.02 & 6.62 & $<.001$ & -0.28 & 0.04 & -7.85 & $<.001$ & 0.04 & 0.02 & 1.82 & .07 & -0.02 & 0.05 & -0.50 & .60 \\
\hline
\end{tabular}

antie verklaard door de drie aspecten van een leerklimaat wanneer rekening gehouden wordt met de onderlinge samenhang tussen de afhankelijke variabelen.

\section{- Stress op het werk}

De derde onderzoeksvraag behandelt de invloed van leerklimaat op de aanwezigheid van stress op het werk. De resultaten van de multivariate regressie tonen de samenhang tussen de verschillende aspecten van het leerklimaat en de afwezigheid van stress op het werk. Steun van de collega's en steun van de leidinggevende vertonen een significante negatieve samenhang. Voor beslissingsruimte en initiatief daarentegen is een positief verband te vinden. Dit wijst erop dat meer steun van de leidinggevende of collega's samenhangt met een lagere mate van stress op het werk. Hoe hoger de mate van beslissingsruimte en initiatief, hoe meer stress op het werk ervaren wordt. Alle onafhankelijke variabelen samen verklaren $14.88 \%$ van de variantie. De belangrijkste verklarende variabele is beslissingsruimte en initiatief (tabel 7).

- Motivatie en inzet

Uit de factoranalyse is gebleken dat motivatie en inzet zich splitsen in twee verschillende factoren, namelijk motivatie en inzet, en negatieve emoties bij faal- 
ervaring. Beide factoren werden opgenomen als afhankelijke variabele. De multivariate regressieanalyse toonde aan dat enkel ruimte voor beslissingen en initiatief, en steun van de collega's, significante positieve voorspellers waren van de motivatie en inzet van een werknemer $\left(R^{2}=16.36 \%\right)$. Negatieve gevoelens bij falen werden enkel door ruimte voor beslissingen en initiatief significant voorspeld. Bovendien kan worden opgemerkt dat dit model slechts $3.18 \%$ van de variantie kan verklaren, wat opmerkelijk lager is in vergelijking met de andere afhankelijke variabelen.

\section{- De relatie tussen leerklimaat en de antecedenten van een succesvolle organisatieontwikkeling}

Tot nu toe werden de resultaten per afhankelijke variabele gepresenteerd; bij een multivariate regressie wordt echter ook een multivariaat model geschat, waarin nagegaan wordt of de onafhankelijke variabelen het geheel van de afhankelijke variabelen significant voorspellen. De resultaten van de Pillai trace test tonen dat zowel ruimte voor beslissingen als initiatief ( $\lambda_{\text {pillai }}=.35$, Approx. $F(4,835)=$ $112.86, p<.001)$, sociale steun van collega's $\left(\lambda_{\text {pillai }}=.05\right.$, Approx. $F(4,835)=$ $11.47, p<.001)$, als sociale steun van de leidinggevende $\left(\lambda_{\text {pillai }}=.10\right.$, Approx. $F(4,835)=23.31, p<.001)$ significant bijdragen tot de voorspelling van de antecedenten die belangrijk zijn voor het succesvol ontwikkelen van een organisatie.

\section{Discussie}

\subsection{Conclusie}

Op basis van het onderzoek kunnen we concluderen dat de percepties van het leerklimaat van de organisatie samenhangen met verschillende antecedenten die binnen de organisaties belangrijk geacht worden voor het succesvol ontwikkelen van een organisatie. Meer concreet zijn drie facetten van het leerklimaat, namelijk beslissingsruimte en initiatief, steun van de leidinggevende en steun van de collega's, in sterke mate gerelateerd aan de organisatiebetrokkenheid en job tevredenheid van werknemers in de organisatie. Het onderzoek van Mikkelsen en Grønhaug (1999) en de studie van Tarrini (2004) wezen ook op een positief verband tussen leerklimaat en organisatiebetrokkenheid. Daarbovenop stellen Mikkelsen en Grønhaug (1999) dat leerklimaat ook een vrij sterke samenhang vertoont met job tevredenheid.

Wat stress op het werk betreft, kan er worden geconcludeerd dat de factor beslissingsruimte en initiatief samenhangt met een hogere mate van stress op het werk. Wanneer werknemers meer keuzes kunnen maken, betekent dat ook dat ze verantwoordelijk zijn voor deze keuzes; dit kan een zekere druk en stress met zich meebrengen. Een mogelijke verklaring voor dit resultaat is dat de stress op het werk hoger is bij een hogere autonomie omdat de taakvereisten dan ook hoger zijn (Yiou \& Shaolin, 2011). Vorig onderzoek toonde reeds dat hogere taakvereisten samenhangen met hogere stressniveaus (Panari, Guglielmi, Simbula \& Depolo, 2010). De steun van de leidinggevende en de steun van de collega's daarentegen zijn geassocieerd met lagere niveaus van stress op het werk. Mikkelsen et 
Eva Kyndt \& Filip Dochy

al. (1998) vonden eveneens dat werknemers die hoog scoorden op de aanwezigheid een leerklimaat, laag scoorden op stress op het werk.

In het kwantitatieve luik van het onderzoek werd motivatie en inzet opgedeeld in enerzijds motivatie en inzet, en negatieve emoties bij falen anderzijds. De resultaten tonen aan dat de factor beslissingsruimte en initiatief een significante voorspeller is voor beide aspecten. Uit de regressieanalyse blijkt dat hoe hoger de score op deze leerklimaatfactor is, hoe hoger de score op negatieve emoties bij faalervaringen is. Dit resultaat kan erop wijzen dat werknemers het belangrijk vinden om hun werk goed te doen, dat ze hiervoor gemotiveerd zijn en zich dus bijgevolg niet gelukkig voelen wanneer ze hier niet in slagen. Er werd geen voorgaand onderzoek teruggevonden dat deze relatie onderzocht; toekomstig onderzoek is dus nodig om na te gaan of deze relatie ook gevonden kan worden in andere steekproeven.

De gevonden verbanden hebben enkele praktische implicaties voor de verschillende betrokkenen binnen profit- en non-profitorganisaties (zie ook de praktijkbox). Organisaties binnen de huidige kennissamenleving hechten meer en meer belang aan het hebben van een gunstig leerklimaat. Expliciteren wat een leerklimaat inhoudt en waar een leerklimaat invloed op heeft, kan opleidingsverantwoordelijken ondersteuning bieden als argumentatie naar andere stakeholders toe. 'Differing aspects of an organization's learning environment, or learning climate, support either individual, team, or organizational levels of learning associated with different individual, team, and organizational outcomes' (Clarke, 2005, p. 188). Het bewust werken aan een kwaliteitsvol leerklimaat heeft invloed op alle betrokkenen binnen een organisatie. In onze theoretische achtergrond haalden we aan dat het uitgangspunt is dat een organisatie zich slechts succesvol kan ontwikkelen wanneer de medewerkers zich succesvol ontwikkelen (Van Dongen, 2003) en dat de essentie van een succesvolle organisatie dus wordt gevormd door mensen die het verschil maken (Altink et al., 2004; Den Breejen, 2009; Pol, 2008). In het kwalitatieve onderzoek werd dit uitgangspunt empirisch bevestigd door de respondenten. Wanneer aan hen gevraagd werd welke antecedenten zij belangrijk vinden voor een succesvolle organisatieontwikkeling, lag de nadruk op antecedenten die rechtstreeks gerelateerd zijn aan het functioneren van individuele werknemers (bijv. motivatie, job tevredenheid). In het tweede luik van het onderzoek werd vastgesteld dat de percepties van het klimaat in de organisatie gerelateerd zijn aan deze antecedenten. Het is dus voor organisaties enerzijds belangrijk dat ze genoeg aandacht hebben voor het functioneren van individuele werknemers omdat deze bijdragen tot de ontwikkeling van de organisatie als geheel. Anderzijds zien we ook dat het leerklimaat dat heerst binnen een organisatie hiertoe kan bijdragen en dat organisaties er goed aan doen om de sociale steun binnen de organisatie van collega' en leidinggevenden, en de ruimte voor beslissingen en initiatief te bewaken.

\subsection{Beperkingen en perspectieven voor toekomstig onderzoek}

$\mathrm{Bij}$ het generaliseren van de resultaten van deze studie dienen een aantal beperkingen in acht te worden genomen. Allereerst kan worden opgemerkt dat het 
onderzoek uitgevoerd werd met de medewerking van vrijwillige deelnemers. Dit kan potentieel voor een positievere inschatting van de relaties gezorgd hebben, omdat deelnemers het thema van dit onderzoek misschien belangrijker vonden dan werknemers die besloten om niet deel te nemen. Bovendien kan worden opgemerkt dat de meerderheid van de deelnemers hoger geschoold is en een bediende statuut ${ }^{3}$ heeft. Mogelijk kunnen de resultaten dus niet veralgemeniseerd worden voor lager geschoolde arbeiders. Daarnaast werden de data voor het kwantitatief onderzoek verzameld via zelfrapportagevragenlijsten. Een mogelijk gevolg hiervan is dat de resultaten mogelijk een overschatting van de relaties weergeven, ook wel gekend als gedeelde methodevariantie. De exploratie van de structuur van de vragenlijst leidde ertoe dat slechts drie facetten van het leerklimaat onderscheiden werden. De facetten ontwikkelingspotentieel, collaboratief potentieel en innovatief klimaat kwamen niet naar voren. Bijgevolg konden deze facetten ook niet ingebracht worden in de analyses en kunnen we dus geen uitspraken doen over de samenhang tussen deze facetten en de antecedenten voor een succesvolle organisatieontwikkeling. De verklaring hiervoor kan enerzijds worden gezocht in de opbouw van het instrument, maar ook in de oordelen van de deelnemers. Verder onderzoek dient uit te wijzen of het niet naar voren komen van deze facetten een beperking is van het instrument, of een weerspiegeling is van het feit dat de deelnemers geen onderscheid maken tussen deze facetten.

Uit het kwalitatief onderzoek kwamen verschillende antecedenten naar voren die belangrijk geacht werden voor het succesvol ontwikkelen van organisaties. De vele antecedenten illustreren de complexiteit van het succesvol ontwikkelen van organisaties. De huidige studie had aandacht voor de rol van een leerklimaat binnen professionele organisaties. Dit exploratief onderzoek kan een opstap zijn naar toekomstig onderzoek. Het zou bijvoorbeeld interessant zijn indien toekomstig onderzoek meer aandacht zou hebben voor de interactie tussen individu en organisatie. Zo toonden de resultaten dat werknemers die ruimte voor beslissingen en initiatief ervaren, een hogere job tevredenheid, motivatie en inzet, en organisatiebetrokkenheid rapporteren, maar ook hogere niveaus van stress op het werk. Deze resultaten tonen aan dat het belangrijk is dat gezocht wordt naar een gezond evenwicht. Dit evenwicht kan echter op een andere manier vorm krijgen voor verschillende individuen, afhankelijk van zowel hun persoonlijke kenmerken als de kenmerken van de organisatie waarin ze actief zijn. Een tweede mogelijke piste voor toekomstig onderzoek betreft de rol van het beleid van de organisatie omtrent opleiding en ontwikkeling binnen organisaties en de percepties van werknemers hieromtrent. Mogelijke onderzoeksvragen zouden zich kunnen toespitsen op de mate waarin het beleid weerspiegeld wordt in de percepties van werknemers, en welk beleid de meest positieve gevolgen heeft voor het leerklimaat en de ontwikkeling van de organisatie. 


\section{Praktijkbox}

Wat betekenen de resultaten voor de praktijk?

- Uit het kwalitatieve onderzoek kwam naar voren dat organisaties verschillende antecedenten belangrijk achtten voor hun ontwikkeling. Voor zowel de profit- als non-profitsector kwamen job tevredenheid, en motivatie en inzet van de werknemers naar voren als een belangrijke antecedent.

- In het algemeen tonen de resultaten dat de percepties van een gunstig leerklimaat positief samenhangen met verschillende aspecten die belangrijk zijn voor een succesvolle ontwikkeling van een organisatie. In de huidige continu veranderende samenleving is het belangrijk dat organisaties hier aandacht voor hebben.

- De resultaten van het huidige onderzoek bieden indicaties voor de vraag welke antecedenten beïnvloed worden door een leerklimaat. Hierbij kwam beslissingsruimte en initiatief als de belangrijkste factor naar voren. Het hebben van beslissingsruimte en initiatief binnen de organisatie zou een positief effect hebben op de organisatiebetrokkenheid, job tevredenheid, en motivatie en inzet van werknemers. Ruimte voor beslissingen en initiatief kan echter wel de stress op het werk van werknemers verhogen. Daarom is het belangrijk om op zoek te gaan naar een gezond evenwicht

\section{Noten}

1 De term antecedenten verwijst naar aspecten van de organisatie die actoren uit de praktijk verbinden met een succesvolle ontwikkeling van de organisatie. Antecedent verwijst hier niet naar een causale factor.

2 De volledige vragenlijst is te verkrijgen bij de auteurs.

3 Het bediende statuut is eigen aan de Belgische context en verwijst naar het type contract dat een werknemer heeft. In principe is een arbeider iemand die hoofdzakelijk handenarbeid verricht en een bediende iemand die in hoofdzaak intellectuele arbeid verricht. Het onderscheid in dit type contract hangt samen met verschillende rechten en plichten voor zowel werkgever als werknemer. Momenteel is de Belgische regering echter volop bezig met het ontwikkelen van een eenheidsstatuut waarbij dit onderscheid weg zou vallen.

\section{Literatuur}

Alliger, G., Tannenbaum, S., Bennett, W., Traver, H. \& Shortland, A. (1997). A meta-analysis on the relations among training criteria. Personnel Psychology, 50, 341-358.

Altink, W., Schoonman, W. \& Seegers, J. (2004). Menselijk kapitaal. De ontwikkeling van mensen in organisaties. Assen: Van Gorcum. 
Antecedenten van een succesvolle organisatieontwikkeling en hun relatie met het leerklimaat van de organisatie: een 'mixed method'-studie

Bergenhenegouwen, G.J., Mooijman, E.A.M. \& Tillema, H.H. (2002). Strategisch opleiden en leren in organisaties (3de ed.). Groningen: Wolters-Noordhoff.

Biemans, P. (2010). Jaarboek Personeelsmanagement 2010. Deventer: Wolters Kluwer Belgium.

Blau, G., Andersson, L., Davis, K., Daymont, T., Hochner, A., Koziara, K., Portwood, J. \& Holaday, B. (2008). The relation between employee organizational and professional development activities. Journal of Vocational Behaviour, 72, 123-142.

Brief, A.P. (1998). Attitudes in and Around Organizations. Thousand Oaks, CA: Sage.

Cartwright, S. \& Cooper, C. (2009). The Oxford handbook of original well-being. Oxford: Oxford University Press.

Clarke, N. (2005). Workplace learning environment and its relationship with learning outcomes in healthcare organizations. Human Resource Development International, 8, 185-205.

Coetzer, A. (2007). Employees' perceptions of their workplaces as learning environments. Journal of Workplace Learning, 19, 417-434.

Cohen, J. (1988). Statistical power analysis for the behavioral sciences (2nd ed.). New Jersey: Lawrence Erlbaum.

Cohen, L., Manion, L. \& Morrison, K. (2007). Research methods in education (6th ed.). Oxford: Routledge.

Connell, A.O. \& Phillips, J.J. (2003). Managing employee retention: A strategic accountability approach. Burlington: Elsevier.

Cooper, C.L. \& Cartwright, S. (1994). Healthy mind; healthy organization - a proactive approach to occupational stress. Human Relations, 47, 455-471.

Curry, J.P., Wakefield, D.S., Price, J.L. \& Meuller, C.W. (1986). On the causal ordering of job satisfaction and organizational commitment. The Academy of Management Journal, 29, 847-858.

Dalgran, A.S. \& Gard, G.E. (2009). Soft values with hard impact - a review of stress reducing interventions on group and organizational level. Physical therapy review, 6, 369-381.

DeCorte, T. \& Zaitch, D. (2009). Handboek kwalitatieve methoden in de criminologie. Leuven/Den Haag: Acco.

DeCotiis, T.A. \& Summers, T.P. (1987). A path analysis of a model of the antecedents and consequences of organizational commitment. Human Relations, 40, 445-470.

Den Breejen, J.D. (2009). De high performance organisatie. Een integrale aanpak. Management van leren én veranderen. Alphen aan den Rijn: Kluwer.

De Rick, K., Van Valckenborgh, K. \& Baert, H. (2004). Naar een positiever leerklimaat in Vlaanderen. Leuven: Hoger Instituut Voor de Arbeid.

Eagly, A.H., Johannesen-Schmidt, M.C. \& Van Engen, M.L. (2003). Transformational, transactional and laissez faire leadership styles: A meta-analysis comparing women and men. Psychological Bulletin, 129, 569-591.

Ellström, P.-E. (2001). Integrating learning and work: Problems and prospects. Human Resource Development Quarterly, 12, 421-35.

Hambleton, R.K. (1994). Guidelines for adapting educational and psychological tests: A progress report. European Journal of Psychological Assessment, 10, 229-244.

Hargreaves, A. (2003). Teaching in the knowledge society: Education in the age of insecurity. New York: Teachers College Press.

Harrison, M.A. (1990). Organisatiediagnose: Methoden, modellen, processen. Assen: Van Gorcum.

Hyun, Y. (2007). The effects of organizational climate on training transfer. The Korean Journal for Human Resource Development, 9, 45-60. 
Jackson, R.D., Knight, S.C., Lindholm, J.E. \& Rothwell, W.J. (2005). Career planning and succession management: Developing your organisation's talent - for today and tomorrow. Westport: Greenwood Publishing Group.

Jamal, M. (1984). Job stress and job performance controversy: An empirical assessment. Organizational Behavior and Human Performance, 33, 1-21.

Klarenberg, K., Van Moorsel, M. \& Poell, R.F. (1996). Leerklimaat op de werkplek: Op zoek naar een meetinstrument. Opleiding en Ontwikkeling, 9 (7/8), 22-27.

Konings, J., Sels, L. \& Vanormelingen, S. (2008). Het effect van bedrijfsopleidingen op de productiviteit van ondernemingen in de voedingsindustrie. KU Leuven: Faculteit economische en bedrijfswetenschappen.

Kouwenhoven, C.P.M., Van Hooft, P.L.R.M. \& Hoeksema, L.M. (2005). HR Management: De praktijk van strategisch personeelsmanagement (2de ed.). Alphen aan den Rijn: Kluwer.

Kyndt, E. \& Onghena, P. (in press). Hierarchical linear models for researching professional learning: Relevance and implications. In S. Billett, C. Harteis \& H. Gruber (Eds.), International handbook of research in professional practice-based learning. Springer.

Levering, B. \& Smeyers, P. (2003). Opvoeding en onderwijs leren zien: Een inleiding in interpretatief onderzoek. Amsterdam: Uitgeverij Boom.

Martins, E.C. \& Terblanche, F. (2003). Building organisational culture that stimulates innovation and creativity. European Journal of Innovation Management, 6, 64-74.

Mayer, K.U. \& Solga, H. (2008). Skill formation: Interdisciplinary and cross-national perspectives. Cambridge: Cambridge University Press.

Mikkelsen, A. \& Grønhaug, K. (1999). Measuring organizational learning climate: A crossnational replication and instrument validation study among public sector employees. Review of Public Personnel Administration, 19, 31-44.

Mikkelsen, A., Saksvik, P.O. \& Ursin, H. (1998). Job stress and organizational learning climate. International Journal of Stress Management, 5, 197-209.

Mortelmans, D. (2009). Handboek kwalitatieve onderzoeksmethoden. Leuven: Acco.

Noppe, K., Lernout, B., Heye, T. \& Frederix, R. (2006). Economische topper 5: Bedrijfswetenschappen. De Boeck: Antwerpen.

Örtenblad, A. (2002). The learning organization: towards an integrated model. The Learning Organization, 11, 129-144.

Panari, C., Guglielmi, D., Simbula, S. \& Depolo, M. (2010). Can an opportunity to learn at work reduce stress? A revisitation of the job demand-control model. Journal of Workplace Learning, 22, 166-179.

Pearn, M., Roderick, C. \& Mulrooney, C. (1995). Learning organizations in practice. London: McGraw-Hill.

Pedler, M., Burgoyne, J. \& Boydell, T. (1997). The learning company: A strategy for sustainable development. London: McGraw-Hill.

Pepermans, R. \& Rammant, P. (2003). Retentiemanagement. Mechelen: Wolters Kluwer Belgium.

Peugh, J.L. (2010). A practical guide to multilevel modelling. Journal of School Psychology, 48, 85-112. doi:10.1016/j.jsp.2009.009.002.

Pinder, C.C. (1998). Work motivation in organizational behavior. Upper Saddle River, NJ: Prentice Hall.

Pol, E. (2008). Strategisch HRM: Erkennen, begrijpen en doen. Assen: Van Gorcum.

R Development Core Team (2012). R: A language and environment for statistical computing. R Foundation for Statistical Computing: Vienna, Austria. Retrieved on July 19th, 2012, from http://www.R-project.org/.

Raggl, A. \& Troman, G. (2007). Turning to teaching: Gender and career choice. British Journal of Sociology of Education, 29, 581-595. 
Rath, T. \& Harter, J. (2010). Well being: The five essential elements. New York, NY: Gallup Press.

Robbins, S. (2005). Gedrag in organisaties. Amsterdam: Pearson Education Benelux.

Rothwell, W.J. (2008). Adult learning basics. Alexandria, VA: ASTD Press.

Schermer, K.J. \& Quint, P. (2008). De organisatie als hulpmiddel. Houten: Bohn Stafleu van Loghum.

Sempane, M.E., Rieger, H.S. \& Roodt, G. (2002). Job satisfaction in relation to organizational culture. Journal of Industrial Psychology, 28, 23-30.

Sprenger, C.C. \& Van Oort, W.J. (1998). Naar een markt van kennis en leren. Kennismanagement als organisatieprincipe. Den Haag: Elsevier Bedrijfsinformatie.

Sree Rekha, K.R. \& Kamalanabhan, T.J. (2010). A study on the employee turnover factors in ITES/BPO sector. International Journal of Learning and Change, 4, 164-180.

Staples, S., Hulland, J.S. \& Higgins, C.A. (1998). A self-efficacy theory explanation for the management of remote workers in virtual organizations. Organization Science, 10, 758-776.

Swart, J., Mann, C., Brown, S. \& Price, A. (2005). Human resources development: Strategy and tactics. Amsterdam: Elsevier Butterworth-Heinemann.

Taris, T.W. \& Schreurs, P.J.G. (2009). Well-being and organizational performance: An organizational-level test of the happy-productive worker hypothesis. Work and Stress, 23, 120-136.

Tarrini, M.G. (2004). The development and application of a bespoke organisational learning competency framework in a global organisation. Unpublished doctoral dissertation, Cranfield University, UK.

Tziner, A., Fisher, M., Senior, T. \& Weisberg, J. (2007). Effects of trainee characteristics on training effectiveness. International Journal of Selection and Assessment, 15, 167-174.

Van Biesen, F. (1989). Alledaags leren in arbeidsorganisaties. Ontwerp: Tijdschrift voor volwasseneneducatie, 1, 4-11.

Van den Berg, M. (2009). Betrokkenheid en motivatie van de nieuwe generatie. Niet-gepubliceerde master thesis, Erasmus Universiteit Rotterdam.

Vandecasteele, A. \& Bonte, A. (2005). Levenslang leren voor iedereen: Verslag van een terreinverkenning. Gent: Riso Gent vzw.

Vanderstraeten, A. (2001). HRM in social profit- en publieke organisaties. Antwerpen: Standaard Uitgeverij.

Van Dongen, T. (2003). Competentiemanagement. En dan? Een mensgerichte visie op competentiemanagement. Zaltbommel: Thema.

Watkins, K.E. \& Marsick, V.J. (1993). In action: Creating the learning organization. Alexandria: American Society for Training and Development.

Westerberg, K. \& Hauer, E. (2009). Learning climate and work group skills in care work. Journal of Workplace Learning, 21, 581-594.

Yiou, G. \& Shaolin, Y. (2011). Employee satisfaction management on job-related stress. The mechanism between middle level manager's leadership and knowledge worker's autonomy. Unpublished master thesis, Linköping Universitet, Linköping, Sweden.

\section{The relation between learning climate and antecedents for a successful development of organizations}

Eva Kyndt \& Filip Dochy, Gedrag \& Organisatie, volume 26, December 2013, nr. 4, pp. 357-378. 
Eva Kyndt \& Filip Dochy

The current study investigates the relation between an organizational learning climate and the antecedents of successful development of organizations. In order to answer this general research question, two studies were conducted. In a first qualitative study the goal was to determine which antecedents were considered important for successful development of the organization to be possible. In total, 55 semi-structured interviews were administered. A selection of antecedents, considered important by these respondents (middle management and management), was included in a second quantitative survey in which 863 employees participated. Results show that autonomy - as a part of learning climate - has a positive effect on the organizational commitment, job satisfaction and motivation of employees. Moreover, social support from colleagues and managers is also positively related to these antecedents.

Key words: learning climate, organizational development, organizational commitment, job stress, job satisfaction 